$12-2018$

\title{
Denial: David Irving, and the Complexities of Representing a Holocaust Denier
}

\author{
Kirril Shields \\ The University of Queensland \\ Ted Nannicelli \\ The University of Queensland \\ Henry Theriault \\ Worcester State University
}

Follow this and additional works at: https://digitalcommons.usf.edu/gsp

\section{Recommended Citation}

Shields, Kirril; Nannicelli, Ted; and Theriault, Henry (2018) "Denial: David Irving, and the Complexities of Representing a Holocaust Denier," Genocide Studies and Prevention: An International Journal: Vol. 12: Iss. 3: $40-51$.

DOI:

https://doi.org/10.5038/1911-9933.12.3.1573

Available at: https://digitalcommons.usf.edu/gsp/vol12/iss3/8

This Conference Proceeding is brought to you for free and open access by the Open Access Journals at Digital Commons @ University of South Florida. It has been accepted for inclusion in Genocide Studies and Prevention: An International Journal by an authorized editor of Digital Commons @ University of South Florida. For more information, please contact digitalcommons@usf.edu. 


\title{
Denial: David Irving, and the Complexities of Representing a Holocaust Denier
}

\author{
Kirril Shields \\ The University of Queensland \\ Brisbane, Australia \\ Ted Nannicelli \\ The University of Queensland \\ Brisbane, Australia \\ Henry Theriault \\ Worcester State University \\ Worcester, Massachusetts, USA
}

\section{Introduction}

For some decades now, historian David Irving has been at the center of scandal, including arrest and incarceration in Austria in 2005-2006 for Holocaust denial. His published histories on persons such as Adolf Hitler and Erwin Rommel have received mixed reception, especially among scholars, and his self-promotional YouTube videos show him to be a racist and a misogynist. Yet perhaps Irving's most controversial moment was the trial he brought against Holocaust scholar Deborah Lipstadt, known today as Irving versus Penguin Books Limited, Deborah E. Lipstadt. ${ }^{1}$ Irving accused Lipstadt (and her book's publisher) of libelous representation in her book Denying the Holocaust, and it is this trial that is at the heart of Mick Jackson's 2016 film Denial.

The film stars Rachel Weisz as Deborah Lipstadt and Timothy Spall as David Irving, and it premiered at the Toronto Film Festival in 2016. The film was subsequently nominated for a British Academy Film Award for Best Film, and it has been positively reviewed in the press, the Guardian calling the film an "overwhelmingly relevant assertion of the truth." ${ }^{2}$

Denial was selected by the committee of the 2017 International Association of Genocide Scholars conference for a number of reasons. First, the film was relatively fresh and had only just premiered in Australia. Second, the debate over Holocaust denial had recently reignited on Australian university campuses after pamphlets and posters were distributed nation-wide that questioned the legitimacy and historical veracity of the Holocaust. Third, the film intended to introduce mainstream viewers to the world of the Holocaust and Holocaust denial, and the choice of the filmmaker was to fictionalize rather than employ a genre such as documentary. These were social and filmic influences that the panel took into consideration when discussing Denial.

\section{The Risk of Hypocrisy by Kirril Shields}

Let me start with something of an anecdote. I lived for three and a half years in Bermondsey, London, a borough that boasts the highest density of council housing in South London. In my experience, cafes in the area cook fry-ups, of which there are a good number (those places where you go to eat fried eggs, sausages, fried bread and so on). These cafes do not serve bagels. So why is it that the character of Deborah Lipstadt in Mick Jackson's 2016 film Denial, asks for a bagel in one of these eateries? Why not a cup of tea, or a fried egg on toast? Why not nothing? Why a bagel in a cafe not traditionally known for bagels?

My point here being representation and how filmmakers wish to emphasize a particular trait or typology. The bagel is an important insert within the film because this is what Jews eat. The bagel is a marker, a somewhat clichéd symbol among the many other symbols inserted in the film as a means of denotation. Watch for the row of expensive cars, the metal thorn in the foot, the tattoo on the arm, the t-shirts the character of Lipstadt wears, sandwiches in the cupboard, plastic cups intended for red wine; all are markers concerned with building a particular representation.

\footnotetext{
${ }^{1}$ Irving v. Penguin Books Limited, Deborah E. Lipstadt, EWHC Queen's Bench 115, April 11, 2000.

${ }^{2}$ Peter Bradshaw, "Denial Review: Overwhelming Relevant Assertion of Truth," Guardian, January 27, 2017, accessed

November 1, 2017, www.theguardian.com/film/2017/jan/26/denial-review-holocaust-rachel-weisz.
} 
Admittedly, this is typical of film and theatre, and something Bertolt Brecht would have referred to as gestus, which, by loose definition, are single or repeated actions that, either on stage or onscreen, are socially coded. ${ }^{3}$ They tell us something about a character and where they might be positioned, socially or culturally. The plastic cups of red wine preferred by the character Richard Rampton QC (played by Tom Wilkinson) tells us that he is a simple man of simple taste, who thinks glass or crystal an indulgent frivolity. Alternatively, that time is too precious to waste with the washing up. Denial is (as are most films), littered with socially coded signs akin to the cups and the bagel.

These codes, however, extend beyond quite obvious and rudimentary social and cultural identifiers, and include the more nuanced and/or less obvious, such as facial expression, body language, filmic angle, soundtrack, and so forth. Actors, in the very process of becoming another being, adopt various identifiers to show class and social habit, cultural customs, and these adaptors inform backstory, even tell us something about the character's opinions on matters. Think what a hand on a hip suggests, or the way a cigarette is held. Rachel Weisz's portrayal of Lipstadt is reliant on various codifiers, including the habit of a hurried walker and fast talker, suggesting a strong female character, self-determined, who can think on her feet. There is also a lack of partner, with the exception of a dog, suggesting Lipstadt a woman with little need of a human relationship.

Here I want to move past this character of Lipstadt and all that is emblematically embedded in her character, to discuss the performance by Timothy Spall, and his rendering of the Holocaust denier, David Irving. Spall is also reliant on symbolic gestures as a means of fleshing out the character of Irving. The actor bends a certain way to possibly symbolize a lack of integrity; he holds spectacles to enhance a sense of learnedness, and so on. Irving, in real life, is a 79-year-old author of World War Two histories (mostly), who sides politically with the Right, and for some while has denied (denies?) the Holocaust. In Spalding's characterization, any number of socially coded actions become apparent, intended to signal the author's social status, and his like or dislike of certain peoples. This is no better epitomized than in the scene where Irving peers out from his lounge room window unblinking, somewhat akin to Anthony Hopkin's portrayal of serial killer Hannibal Lecter. He stares after two young lawyers working for Lipstadt's publisher (who Irving is attempting to sue), as they walk from his house. Why is it the character Irving refrains from blinking? Because arseholes do not blink, or so seemingly suggests Hollywood.

Until viewing Denial, all I knew of David Irving was that he was British and that he was a Holocaust denier. I had never read his books, did not know what he looked like, and was never interested in his account of the Holocaust. Following the screening, having watched hours of Irving as he performs "himself" on his self-produced YouTube clips, having read snippets of his books, here is my very brief opinion of the man. Is he racist? Yes. Is he anti-Semitic? Yes. Is he a misogynist? Yes. Is he a Holocaust denier? Actually, I am not sure given recent revisions of his own ideas. In some YouTube clips Irving does not deny the numbers of Jews who perished in the Reinhardt camps, only contests the numbers that were gassed at Auschwitz. So he seemingly agrees with the figure of 6 or 6.5 million Jews dead, but differs on certain specificities, reminding me of a man who is aging and remains stubborn for no reason than stubbornness alone. In some respects, after watching Irving's self-indulgent YouTube performances, I feel as if in the last year or so he has picked up a copy of Timothy Snyder's Bloodlands: Europe Between Hitler and Stalin and this has had some effect. ${ }^{4}$ But does David Irving advocate for political and social right-wing movements? Yes. So, in summary, regardless of where he sits in relation to the Holocaust nowadays, Irving is definitely a non-blinker.

While Irving may not be the most ethical of individuals, is he the man we see on the screen in Jackson's Denial? In my opinion, he is not the man we see on screen. I admit that I have never personally met the man, and all my knowledge of him is derived from online or published mediums. I therefore base this opinion on certain types of textual evidence. I am also aware that what we see on screen is artistic license, an actor's prerogative. After outlining my own inadequacies and

\footnotetext{
${ }^{3}$ George Brandt, "Brecht, Bertolt," in The Continuum Companion to Twentieth Century Theatre, ed. Colin Chambers (London: Continuum, 2010), accessed June 17, 2017, http://www.oxfordreference.com.ezproxy.library.uq.edu.au/view/10.1093/ acref/9780199754724.001.0001/acref-9780199754724-e-362?rskey=uD4hD5\&result=1.

${ }^{4}$ Timothy Snyder, Bloodlands: Europe Between Hitler and Stalin (London: Vintage, 2010).
} 
acknowledging the fact that film molds and manipulates purposefully, it is important to draw on the core motivation behind the film; that of a libel case, a false statement damaging a person's reputation. And it is here where there's the risk of hypocrisy. Is this film, therefore, a somewhat well intended and morally tenacious case of libel, based on another not so well intended and immoral case of libel? Because if Irving's depiction by Spall, under direction of Jackson, is false, then the film seemingly falls prey to its own accusation. Or, could it be that there is such a thing as well-intended and moral defamation? Here I am not suggesting that actors or directors dismiss hyperbole or over-the-top portrayals of real-life "baddies". And yet, even when taking this into account, given the message at the heart of Denial, is the filmmaker and the production team being somewhat hypocritical?

As a means of attempting to answer this question, I turn to David Irving's histories, his published work, which is a long list of writing that, over the years, has led to time in prison, and bankruptcy. What Irving stands accused of-aside from this seemingly forever-changing interpretation of the Holocaust-is the picking and choosing of history, hence his somewhat positive analysis of Adolf Hitler, and, according to Sir Ian Kershaw, Irving's attempts to exculpate Hitler's role in the Final Solution. ${ }^{5}$ Irving is criticized for selectively choosing aspects of the past that seem to him interesting historical artefact, and relying upon his interpretation to usurp popular and well-regarded scholarship. So he picks and chooses subjectively, constructing characters such as Erwin Rommel, Josef Goebbels, or Hitler in ways sometimes antithetical to tried, tested, known, and well-regarded historical methods. And in opposition to what could be called ethical and moral accounts of a past that attempt to recognize decent scholarship rather than hearsay or speculation (I refer to Irving's reliance on a book written by Fred Leuchter titled The Leuchter Report: The End of a Myth). ${ }^{6}$ As a result, Irving has seen himself in all manner of trouble, hence this particular court case, hence the supposed bankruptcies, hence his time in prison in Austria, and hence being banned from entering Australia.

However, a problem arises when you begin to ponder the film Denial, and the filmmaker's decisions. Has director Mick Jackson done something similar in his direction and choice of character depiction to what Irving is accused of doing in his histories? At the heart of what I am proposing is the responsibility to build a story ethically, something unbiased; a history that provides as accurate a representation as possible. For this is exactly what this film, Denial, is concerned with. It is about defending a person's reputation from ill repute or slanderous motives. Yes, there is that element to the film that proves Irving's history inaccurate in relation to Auschwitz, but the film is also about a writer thinking he has been wrongly portrayed in a book. Then, somewhat ironically, this same person now finds himself being wrongly portrayed in a film about being him wrongly portrayed in a book. I feel like the filmmaker never really understood the complexities of representation, or the social and political nuances at work, or decided representing Irving accurately was not an important consideration given Irving's background. In the director choosing the film's representations, Jackson undermines the film's message and offers opportunities for Irving (and with some right to do so) to accuse the filmmaker of an inaccurate and slanderous representation.

Some accusations are easily defended in relation to Irving's politics and his past deeds, or even when considering some of his published work, in that it would be easy to accuse Irving of being an anti-Semite and then prove this, or to show historical inaccuracy in some of his history. In the case of artistic representation, however, as seen in the film, David Irving would have a legitimate gripe. I feel it is one thing to show a person to be Jewish by having them order a bagel in a London café, but it is quite precarious to insert characteristics that allow Irving, his followers and his beliefs, a moment of exculpation. And this is what this film might enable. It gives opportunity for Irving to show that he has been wronged in representation, and while this does not lessen other racist or misogynistic examples of Irving's self, it does offer him the opportunity to revel in misrepresentation, building on the "hard done by" rhetoric he employs that until now had little substance.

\footnotetext{
${ }^{5}$ Ian Kershaw, The Nazi Dictatorship: Problems and Perspectives of Interpretation (London: Edward Arnold, 1985).

${ }^{6}$ Fred A. Leuchter, The Leuchter Report: The End of a Myth (Newport Beach: Samisdat Publishers, 1988).
} 
One broad question that I believe arises in relation to this last point: is such a concern relevant? Irving is an old man with aging views, who appears very much a narcissist, very much a selfseeking publicity monger. Should we care if this film offers Irving a small reprieve given the overabundance of accusatory evidence that questions his morals and his historiography? Unfortunately, this topic does remain relevant and applicable to generations younger than Irving, because in 2017, some of Irving's younger followers decided to distribute leaflets at Australian university campuses, denying the Holocaust and publicizing the same uneducated rhetoric that Irving himself propagates. While they were quickly gathered up and destroyed by campus security, their presence shows that Irving's ideas remain potent and followed. So I do insist that there is some risk in taking this particular character representation too far from the real, and in doing so providing those who distribute denial leaflets, alongside Irving himself, a legitimate means of debasing or undercutting (or usurping or delegitimizing) those who demand historical and historiographical accuracy. It provides Irving the impetus to question ideas of fairness and accuracy, when his own career has been reliant on the distortion of both.

\section{The Rhetoric of Denial by Ted Nannicelli}

When I arrived at Emory University in 1998, it was with the intention of majoring in English and History. Had I stuck to that plan, I may well have taken a course with Professor Deborah Lipstadt and had a much more interesting perspective on Denial, based on her memoir, History on Trial: My Day in Court with a Holocaust Denier (2005). However, I ended up taking only one history course before my interests permanently shifted to cinema studies and now, not quite twenty years later, I teach in a film and television studies program.

I do not know if my training gives me a much different perspective on this film than any of you probably have-I was often transfixed by the acting performances much like I imagine most viewers are-but it is probably fair to say that in my job I tend to think about the construction of films more than non-specialists. So, that is what I would like to talk about-the construction and, more specifically, the cinematic rhetoric, of Denial.

Considering the film as a rhetorical construction occurred to me as potentially fruitful because the film takes rhetoric as a theme. That is, Denial juxtaposes David Irving's baseless, empty rhetoric against the truth-historical fact as it is presented by Lipstadt and her legal team. What I want to suggest is that there is a tension in the way the film stages this opposition. The tension arises from the fact that rhetoric and truth are not necessarily opposed, a fact that the film's construction itself makes clear enough. For Denial is a largely accurate account of historical events, but one that makes copious use of rhetoric to help its arguments and to elicit sympathy for those arguments and for the film's protagonists.

At this point, one might immediately wonder what could be wrong with a film eliciting our sympathy for Lipstadt and what she represents in this film: the triumph of history, fact, truth, and civility. Of course, the answer is "absolutely nothing". Lipstadt and the principles or ideals with which she is aligned certainly do warrant our sympathies, while Irving and the principles or ideals (such as they are) with which he is aligned warrant our rebuke. But it is precisely because this is so glaringly obvious that Denial's liberal use of rhetoric is so curious and, to my mind, a bit unsettling.

It is very unlikely that many people come to a screening of the film with no knowledge of its content. I would like to think, however, that most people who come to a screening of the film have a clear moral view on the Holocaust, and on those people who have tried to deny that the Holocaust occurred. If I am mistaken about this, then I suppose much of the worry I am about to express about the film's rhetorical structure is misguided. Perhaps, in other words, many viewers come to Denial with enough of an open mind that the film's rhetoric-especially those moments that make it unambiguously clear who we should side with - is indeed warranted. If I am right that most viewers come to the film with the sense that Holocaust denial is a moral wrong and are thus unlikely to have any sympathy for Irving whatsoever, then it remains puzzling to me why the film goes to the rhetorical lengths that it does.

At this point I wish to be a little bit more specific about my claims regarding Denial's rhetoric. What sorts of rhetorical devices do I have in mind? Some are common to many-perhaps mostmainstream Hollywood style movies. One of the most important conventions in such movies is 
Shields et al.

that the films are, in Noël Carroll's words "emotively prefocused" for us. ${ }^{7}$ That is to say, we do not view the events movies represent impartially. Rather, we experience the represented events from a particular perspective that the film's narration affords us, and this perspective emotionally colors our apprehension of those events. I use the term "narration" broadly here to refer to the way in which the film distributes the fictional (or, in the case of non-fiction movies like this one, representational) content. Narration includes things like camera angle, camera distance, sound perspective, and even non-diegetic sound-that is, the musical score accompanying the image track, which of course affectively prefocuses and gives a particular perspective on the represented events in the image track. Consider, for example, the ominous strings playing over the scene at the end of the trial, in which a single question from the judge seems to indicate that Lipstadt's entire defensive strategy might be upended. Or, consider the shift to a major key that emotively focuses the delivery of the verdict.

Of course, most of the most affective prefocusing work in Denial involves engendering our sympathy (or pro-attitudes more broadly) towards Lipstadt. According to a widely-accepted view developed by Murray Smith, there are two main, often interconnected processes by which movies elicit our pro-attitudes towards characters in this way: alignment and allegiance. ${ }^{8}$ Alignment is a formal process by which the narration "aligns" our perspective on the represented events with that of a particular character, usually the protagonist. This happens in two ways: through spatiotemporal attachment, which is a matter of being with or following a character, and through subjective access, which is, as it sounds, a matter of granting us access to a character's subjectivity, including her feelings, beliefs, desires, and so forth. According to Smith, spatio-temporal attachment shows us what characters do, and subjective access reveals what they are thinking or feeling.

One of the more contested elements of Smith's account is the claim that, everything else being equal, increased alignment with a character tends to increase allegiance with the character. ${ }^{9}$ Allegiance, for Smith, involves an evaluative dimension; it can be thought of as a matter of rooting for a particular character. According to Smith, the central way in which allegiance is developed is through the solicitation of moral judgment of characters by viewers. We can think here of the screenwriter's old adage, "if you want the audience to instantly hate a character, have him kick a dog in the first scene".

Smith's theory of character engagement offers an interesting perspective from which to think about Denial, in part because it helps clarify this sense, that the film is doing more rhetorical work than it really needed. As suggested earlier, it seems plausible to think that most viewers come to the film allied with Lipstadt and against Irving. If this is the case, one wonders if it is necessary to frame the Irving character from occluded angles and in shadows to make him appear even more sinister and unknowable. Perhaps the more forceful way of representing Irving's evil character would been to have given us more banal scenes in which he is simply openly racist. I should acknowledge, though, that apparently the scriptwriters went to great lengths to ensure that Irving's dialogue in the film is constituted by things he is on the record as saying.

The filmmakers did not hold themselves to this rule for their portrayal of Lipstadt, however. I also wonder about what I would regard as the "forced" spatio-temporal attachment to the Lipstadt character in her many jogging scenes. Work of attachment here feels particularly forced because the jogging adds nothing to the story, but is such a banal character feature that it gives us no sense of Lipstadt as a person. One possibility is that the jogging scenes afford the opportunity for otherwise unmotivated close-ups of the Lipstadt character, so even if we are not getting true subjective access to her mental states through the narration, we are able to exercise our mind-reading capacities to glean her emotional states and, perhaps, share them, moving us from alignment to allegiance.

It is also possible, of course, that Lipstadt really was or is an avid runner, and this explains why she has this hobby in the film. But given the film's comfort with other rhetorical moves, one wonders why such a bland hobby is not spiced up a bit. It cannot be, logically speaking, because

\footnotetext{
${ }^{7}$ Noël Carroll, The Philosophy of Motion Pictures (Malden: Blackwell Publishing, 2008), 159.

${ }^{8}$ Murray Smith, Engaging Characters: Fiction, Emotion, and the Cinema (Oxford: Clarendon Press, 1995), 6-7.

${ }^{9}$ Smith, Engaging Characters: Fiction, Emotion, and the Cinema, 222-223.
} 
the film is committed to complete factual accuracy to Lipstadt's actual life. Interestingly, the film does erroneously suggest, very explicitly, that Lipstadt is from Queens when in fact she hails from the Upper Westside. It is hard to imagine why the filmmakers would fictionalize this detail unless it is a conscious effort to head off the worn anti-Semitic association between Jewish Americans and wealth. As is well known, the New York's Upper West Side is reputed as one of Manhattan's most affluent neighborhoods, while Queens has a reputation as a rough-around-the-edges working class neighborhood. And numerically speaking, there are many more Jews in Manhattan (and even more in Brooklyn) than there are in Queens. ${ }^{10}$

Why mention such a minor detail-a throwaway line at the end of the film? Because it seems to me indicative of the film's uneasiness around its central assertion: that the truth may not speak for itself, as Lipstadt seems to believe at the film's start. But that the right and the good are the right and the good in part because they do not need to manipulate truth to win their case; they simply need to adduce evidence. In other words, that throwaway line, in which the Lipstadt character claims to be from Queens, seems to me symptomatic of a disturbing anxiety tacit throughout Denial: that the film does not really buy its own putative claims about the sufficiency of simply adducing evidence and presenting facts, since its own construction makes clear that the filmmakers have made deliberate use of film's rhetorical potential in an attempt to solidify viewers' allegiance with the Lipstadt character, and guarantee the right emotional response to the represented events.

To be clear, my claim is not that there is anything intrinsically wrong with movies-even those that are non-fiction, or based on a true story - that make use of cinema's rhetorical potential in the sorts of ways I have outlined. Neither is it that such movies are intrinsically "untruthful" or somehow on par with Irving's manipulation of historical fact. Far from it. Non-fiction films and films based on actual events necessarily represent historical events from a particular perspective and often set out to make arguments. This in no way vitiates their ability or potential to accurately represent historical events and be truthful in that sense.

Rather, my point is that Denial might be socially and politically relevant in a way popular commentators have not recognized. The common claim regarding the film's current relevance is neatly expressed by Peter Bradshaw in his Guardian review: "I find this film and its clear-headed premise rewarding. This reasserts the primacy of truth."11 But perhaps the real relevance of the film is that, in the post-truth age, simply marshaling facts and evidence is not enough to sway people towards the morally right view. Denial tacitly suggests, through its own use of rhetoric, that we, who are on the right side of history and have the facts on our side must also-like the posttruthers-appeal to people's emotions.

\section{Denial, Rhetoric and Reality by Henry Theriault}

The lawsuit by David Irving against Deborah Lipstadt is certainly a fit subject for a serious film. It has all the features, in fact, of a classic Hollywood movie, even a showdown Western: the peaceful protagonist tormented by a nasty bully heading a gang of socially-deviant thugs and who relies on manipulation, intimidation, and violence-though, in the 21st century, this action plays out in a courtroom rather than on Main Street with six guns. To the extent that it tells a much worthier story than most other films, it is certainly laudable.

Given the artistic, ethical, and intellectual vacuity of the vast majority of contemporary films, this is, unfortunately, faint praise. Because its creators chose to take on a major issue of human existence-genocide-as well as one of the most prevalent and complex phenomena-denial (which applies not just to genocide, but also to the health effects of tobacco, global warming, evolutionary theory, political corruption, and more)-its makers have given tacit approval that the film be judged against a higher standard. This standard is the various intellectual and artistic approaches against denial developed over the past half century. We might consider the film on the Armenian Genocide, Ararat, and the genocide's multilayered and multifaceted legacy, including

\footnotetext{
${ }^{10}$ Simone Weichselbaum, "Nearly One in Four Brooklyn Residents are Jews, New Study Finds," New York Daily News June 26, 2012, accessed May 24, 2017, http://www.nydailynews.com/new-york/brooklyn/brooklyn-residents-jews-newstudy-finds-article-1.1100080.

${ }^{11}$ Peter Bradshaw, "Denial Review: Overwhelming Relevant Assertion of Truth."
} 
Shields et al.

denial. ${ }^{12}$ Without doing justice to its complexities, this masterpiece pushes the question of denial in all its dimensions. What is a "fact," and how do we relate to facts - as individual or group/ cultural memories, as the motivation for violent and non-violent political action, as objects of art mediated through a complexly layered traumatic history-should we relate to past facts, and more? How do we communicate facts dear to us or that are traumatic for us to others who have a different relationship to them, or no relationship at all? Ararat takes its name from a mountain, a material object, while Denial takes name from an abstraction; and yet, the former engages denial in a sophisticated, shifting, dynamic manner, and the latter in a mechanical, reductive, simplistic one.

Irving is a "type" and those he appeals to are as well; perhaps that is what is true about the real David Irving, but, then, is he really the story? We have a simple conflict between good and evil, between true and false; in director Atom Egoyan's hands, the topic is probed in ways that the Irving case provides little obvious material for. For a film to have engaged on the topic of Irving in a sophisticated way would have required artistic innovation that is lacking in the literal-minded presentation of the case. Indeed, for the film to reveal much about denial, it would have had to have had a sad, not a "happy," ending - for instance, showing Irving becoming a hero again of neo-Nazis worldwide. For the norm is that our world is pervaded and even molded by denial.

Deborah Lipstadt's History on Trial: My Day in Court with a Holocaust Denier was written before denial was firmly recognized as a phenomenon across genocides, science, and politics. It represented Lipstadt's particular experience of the trial and her approach to the Holocaust, which had generally not been open to being situated in a broader history of genocide and human rights abuses and mass violence. So it might be understandable that the book did not make connections that are rather obvious to anyone who considers denial, and it remained somewhat limited even in regard to Holocaust denial because it did not take account of the complexities of denial wellexposed and analyzed in considerations of other cases, whether denial of genocides of Native North and South Americans; Aborigines in Australia; Armenians, Greeks, and Assyrians in the Ottoman Empire and Turkish Republic; Bosnians in the former Yugoslavia; Rwandans, principally Tutsi, in Rwanda; and many more; or denial of the harms of tobacco, global warming, and so on. To choose to call the film Denial in this context, therefore, was to make a claim for it that was simply untrue and misleading. "Denial" as a general phenomenon, even in reference only to genocide, is not reducible to Holocaust denial. The choice obligated the filmmakers to find some creative means of expanding the focus.

I am not suggesting that those who study the Holocaust or Holocaust denial specifically share such limitations; quite the contrary, some of the most innovative and committed thinkers and activists on denial of other genocides have been Holocaust scholars who are able to balance, in a productive and respectful way, the Holocaust as the referent case of genocide and the importance of recognizing it as part of an overarching history of genocide and its denial. ${ }^{13} \mathrm{I}$ am also not suggesting that those who focus on other genocides and/or their denials are any more open to making connections. Ararat is about the Armenian Genocide and its denial. Yet, in Egoyan's hands, the Armenian Genocide becomes the occasion to reflect on and analyze truly universal concerns. In the same way Hamlet is not about some Danish folks, but about all of us, Ararat is not just about Armenian folks but all of us. It explicitly critically engages other issues, such as homophobia. And it recognizes as a legitimate question why the Armenian Genocide should matter to non-Armenians.

Given all that has been written and discussed regarding denial, Denial's creators clearly missed

\footnotetext{
${ }^{12}$ Ararat, directed by Atom Egoyan (2002; Canada et al.: Alliance Atlantis Communications et al.), 115 min.

${ }^{13}$ A first example is Debórah Dwork, a major Holocaust Scholar who is Rose Professor of Holocaust History at Clark University. In her two decades as Founding Director of Clark's Strassler Center for Holocaust and Genocide Studies, she organized and hosted numerous events and courses that dealt with denials of various genocides. Another example is Terrence Des Pres, whose primary genocide studies work was on the Holocaust, but who also wrote the landmark article on denial of the Armenian Genocide, "On Governing Narratives: The Turkish-Armenian Case," Yale Review 75, no. 4 (1986), 517-531. A third example is Israel W. Charny, who entered the study of genocide through the Holocaust but who did groundbreaking work on genocide denial more generally, including "A Contribution to the Psychology of Denial of Genocide," Genocide E Human Rights: Lessons from the Armenian Experience, special issue, Journal of Armenian Studies 4, nos. 1-2 (1992), 289-306.
} 
an excellent opportunity to extend Lipstadt's range; after all, there was nothing that bound them to a literal rendering of her book and exclusive focus on Holocaust denial. Even as a representation of the Irving trial, the standards of serious historical research and a commitment to accuracy would have required reliance on more than Lipstadt's own representation of events. The same is true of an adequate conceptual analysis of denial; there is no reason that Lipstadt's foundation could not have been expanded to strengthen the film. This is an aesthetic as much as a moral claim.

\section{The Unacknowledged Unseen Context}

Rather than focus on the shortcomings of Denial, it is better to use it as an occasion for positive consideration of what "denial" is and has become by the early 21st century. Western philosophy has always been obsessed with distinguishing "appearance" - how things are perceived-from "reality" - the actual metaphysical truth of what is. Other traditions also have recognized this distinction and sometimes shared the response of rejection of "appearance" in favor of some sense of "reality," typically spiritual/transcendent. In the Western cultural tradition and these others, the uncertainty has sometimes been embraced, for instance in the use of unreliable literary narrators, meditation practice that starts with unsolvable conceptual tensions or puzzles.

This basic binary has been modified in many ways. The standard narrative of Western philosophy has certain "turns" that have recast the opposition in new terms. The "Epistemological Turn" took us from what might be termed the "Metaphysical Era," in which the question of perception was limited to a challenge that could be overcome with proper devotion and practice, to one in which epistemic boundaries could never be escaped. For Plato, for instance, the question of perception was relevant only to the world of appearances, which could be transcended by the philosopher who entered the world of things as they actually are. ${ }^{14}$ Once a person was trained to see the world as it is, the issues of perception dropped out and the thinker had direct access to reality. With the "Epistemological Turn" of the early modern period, philosophers recognized that even our concepts of true reality are bound within epistemic horizons or speculative. ${ }^{15}$ All we can know is what we perceive, not what is. Perception became objective reality, whether with a Berkeleyan, Kantian, or other twist. We became trapped in questions of perception.

The "Linguistic Turn" of the 19th and 20th centuries pushed people back further into themselves, as perception became viewed as bounded by linguistic frameworks. Whether Noam Chomsky's rationalist approach to a natural language forming the bedrock of all thought, the ordinary language logicians for whom linguistic statements became all that philosophical analysis could apply to, or poststructuralists who gave up a notion of a consistent, authored or intentionally created/developed language, but still saw thought and perception as embedded within a given linguistic framework.

This philosophical retreat paralleled and perhaps derived from concretehistorical developments. It posed the challenges that opened the door to both creative and repressive innovations in what we might call the age of denial. It allowed the following political moves a space.

The 1600s saw the rise of critical philosophy and co-requisite natural sciences, politics, and culture. Democracy, individual human rights, complex social unifications (for instance, in the nation or class) all became mechanisms of advancement. The rhetoric of expanded rights, political participation, and more, however, contradicted the obvious reality of newly universal colonialism, slavery, genocide, exploitation, and elite-driven internal repression. If human history had always had war and genocide, conquest and capitulation, in the modern era these became the foundations of a global system. What is more, they were driven forward in a period in which the rhetoric seemed to call for the opposite, yet they thrived. A Marxist might see this as the natural progress of social/political/economic contradictions driving change; while a liberal as the mere resilience

\footnotetext{
${ }^{14}$ See, for instance, Book VII of Plato, The Republic, trans. Benjamin Jowett, Internet Classics Archive, accessed June 10, 2018, classics.mit.edu/Plato/republic.8.vii.html.

${ }^{15}$ Examples of key texts of the Epistemological Turn include René Descartes, Meditations on First Philosophy, 3rd ed., trans. Donald A. Cress (Indianapolis: Hackett, 1993); George Berkeley, Three Dialogues between Hylas and Philonous (Indianapolis: Hackett, 1979).
} 
Shields et al.

of outmoded ideas that required patience for the new progressive ideals to take hold. ${ }^{16}$ Yet, the contradictions were not, generally, resolved by revolutionary overthrow of the regressive regime or reform of laws toward greater fairness and universality. Contrary to the expectation of historical materialism or even a looser Hegelian notion of dialectical progress, the resolution not only left the contradiction intact, but transformed it into the foundation of a novel form of mental-material order. ${ }^{17}$

The result has been a new kind of system in which two opposing forces-appearance and reality, however updated-are connected together toward an overarching oppression. It is not denial alone that is the problem, but denial in its relationship with reality. It is not the case that there are no objective facts in the world; quite the contrary, many are easily accessible and doubting them is the function of denial, though denial is often misrepresented as legitimate Cartesian doubt. It is no longer a question of the opposition of falsity and truth, illusory and actuality, but of control of the variable distance between rhetoric and reality. Here the error of Jean Baudrillard is evident. ${ }^{18} \mathrm{He}$ was right to reject old notions of the relationship of appearance to reality; they capture only a certain one of the many relationships possible. But his postmodern move to hyperreality in which all rhetoric and reality become equally rhetorical, is a grand cover up of what is actually the case. He fails to account for the continued difference between rhetoric and reality and embraces pure rhetoric as the real. Indeed, despite the pretentions of postmodernists obsessed with differentiating the postmodern from the modern, the two supposed eras are part of one Rhetorical Age. Postmodernism is simply the latest misunderstanding of and covering up of denial.

To say "system" is too much. What we have is a chaotic ordering and an ordered chaos, or fluidity between system and anti-system, opposing tension and complementarity, and what is on the continua between these pairings. At times, rhetorical devices support approaches to the truth - here again Ararat comes to mind, though any good work of cinema, drama, literature, static visual art, or music would serve just as well, as this film and other works use aesthetic methods to draw audiences to understandings of challenging political and ethical issues they would not have achieved were they given merely didactic treatments. There is a profound difference between seriously studying the statistics of Auschwitz's functioning and genuinely reading Wiesel's Night; the latter does what the former never can; however important statistics are in their own right, they remain incomplete without an imaging step that recognizes or invests them with their truly human meaning - the suffering, perseverance, luck good and bad, tragedy, indescribability, and more of what this part and the entirety of the Holocaust comprised.

The distance between rhetoric and reality can be understood through examples. At times, in the present US Trump Administration, bald-faced lies are presented as truths in direct contradiction to evidence. These are embraced by many as "alternate facts." In this case, the distance between truth and falsity (denial) is maximized. At other times, the distance is condensed, in order to give credibility to what is not quite true. The concept of "plausible deniability" is an illustration: through it, a leader avoids any evidence of intent to produce bad consequences for a victim group. Indeed, there are times when distance is erased in order to demonstrate the reliability of an authority (a leader, for example), so that he/she/they will later be able to open the gap up again on an issue of more importance. Good genocide deniers, for example, deny the minimum necessary to justify their false conclusions; sloppy ones overreach and are easier to refute.

The more that politically and ethically progressive ideas and practices have taken hold and become expected, the more that the distance between rhetoric and reality has been manipulated. Again, it is not that this gap becomes wider and wider, which might be called the Orwellian model; people are not so stupid as to fall for grand falsifications, at least not all or most people. If all

\footnotetext{
${ }^{16}$ For a key articulation of historical materialism, see Karl Marx and Frederick Engels, The German Ideology, Marx Engels Archive, accessed June 11, 2018, www.marxists.org/archive/marx/works/1845/german-ideology/; for an account of classic progressive liberalism, see John Stuart Mill, On Liberty (Indianapolis: Hackett, 1978).

${ }^{17}$ See Marx and Engels, The German Ideology; Georg Wilhelm Friedrich Hegel, The Phenomenology of Spirit, trans. A.V. Miller (Oxford: Oxford University Press, 1977).

${ }^{18}$ Baudrillard's most comprehensive articulation of the position critiqued here is given in Simulacra and Simulation, trans. Sheila Faria Glaser (Ann Arbor: University of Michigan Press, 1994), especially 1-42
} 
pockets of a society seem to acquiesce, it is because some who are well aware of the falsity in play choose to pretend to confirm as true what is false out of political savvy, self-preservation, or the embrace of advantages the right approach to acquiescence guarantees. Rather than being widened perpetually, the gap is controlled, so that its oscillations become the primary means of political power-over domination.

\section{Rhetoric-Reality}

It is beyond the scope of these brief remarks to give a full accounting of the various ways that the relationship between rhetoric and reality is manipulated, of the two terms and their variations, or of the mechanisms acting on their relationship. But a partial treatment should be instructive.

It might have been that in the 17th Century, with the rise of notions of popular political participation, evidence-based science, et cetera, there was the potential for a new kind of human society. But the Rhetorical Turn that began at that point closed off the possibilities of genuine liberation. Recalling Michel Foucault's notion of the transition from a politics of the "Right of Death" to "Power over Life," 19 through this turn, we went from a period in which power did not need the cover of rhetorical adherence to ideals to one in which power, oppression, and domination have been represented successfully as their opposites. The point of no-return was perhaps the French and Haitian Revolutions, the full complexities of which emerge only when they are treated together (though some might contend that pre-modern Christianity operated as a cover for oppression and exploitation; in this sense, we might see this aspect as a precursor to modern power, as it conflicted with the raw power of kings).

If Friedrich Nietzsche was right to recognize the disconnect between the pre-modern Christian concept of good and its relationship to power and desire, or the desire for power-over, he failed to appreciate the brilliance of the modern/contemporary resolution of that disconnect through the manipulation of rhetoric. For Nietzsche, greater power inhered in a nakedly explicit display of dominance for its own sake, than through the more subtle application of power that is hidden through a reversing denialist dissimulation that renders the action of power and oppression itself invisible and thus all the more impactful, resilient, and far-reaching. ${ }^{20}$ Ayn Rand's literary crudities are mirrored in her intellectual ones (even beyond her vulgar, reductive, simple-minded reading of Nietzsche), where she fails to appreciate Ellsworth Toohey as the rightfully dominant figure in The Fountainhead and far more worthy (not morally, of course, because there are no morally worthy characters in anything written by Rand) and interesting than Howard Roark, who is more a dog than a person, with childish-macho desires hardly worth bothering about. ${ }^{21}$

If I have argued that we inhabit a rhetorical age in which the relationship between rhetoric and reality is the focus of and guarantor of power-over, readers might see this as even more pessimistic than previous attempts to engage this split. Many postmodernists, in fact, embrace as liberatory the purely rhetorical as the entire universe of human existence. But my position is no less favorable, due to a simple reversal. With only a few noteworthy exceptions such as Nietzsche, the core quest of Western philosophy has been understood to be the attainment of truth by overcoming obstacles and barriers erected on the path to it. For Plato, this was a 40-year process, for Hegel it required two millennia and more of public progress. What the age of denial has taught is that, at least by the modern era, the truth is pretty straightforward to grasp and record. Denial is about moving us away from a hold on the truth, and the illusion that the truth is somehow elusive and difficult to reach is a key foundation that allows denial the full range it has in the modern/postmodern world.

\footnotetext{
${ }^{19}$ Michel Foucault, "Right of Death and Power over Life," The History of Sexuality Vol. 1: An Introduction, reissue ed. (London: Vintage, 1990).

${ }^{20}$ See Friedrich Nietzsche, On the Genealogy of Morals, trans. Walter Kaufmann and R.J. Hollingdale, in On the Genealogy of Morals and Ecce Homo (New York: Vintage Books, 1989), 15-166.

${ }^{21}$ Ayn Rand, The Fountainhead, 25th ed. (New York: Signet, 1996).
} 
Examples abound. It was after the 1997 Bringing Them Home ${ }^{22}$ report offered compelling evidence of what Australians had done to the indigenous inhabitants of the continent they colonized that a backlash ensued that eroded much of the progress made on the issue that far. ${ }^{23}$ In 1992, as decades of slow progress culminated in a widespread discussion of the legacy of Columbus' genocidal conquest of the "New World," an aggressive backlash characterized by violent rhetoric and explicit, unabashed celebrations of the destruction of Native Americans reasserted genocidal racism into the heart of US political discourse (where denial had covered it for some time). The White Man's burden, captured so well in John Stuart Mill's paternalistic views of the colonized, recast oppression of indigenous peoples across the globe as if a service was being done for them, not to the great benefit of, but to the detriment of colonizers. ${ }^{24}$ The Armenian Genocide was widely known and unquestioned across the world and even in Turkey in 1919, but by the 1920s denial had begun its erosion of the obvious truth. We see the same trajectory regarding Rwanda and many other cases. Denial is always there, as the air we breathe, but continually basic "brute" facts of human society and politics insert themselves into the field of denial. In the moment of assertion, yes, the truth is evident, but then the action of denial erodes certainty as water rushing over granite gradually scrapes it away.

So we come back to the film Denial. All these features of denial and, more to the point, the fact that we live in an age of denial and that denial is the key concept of the modern/postmodern era and the mechanism of its most devastating harm (if the global destruction of climate change, which is now authorized through denial, is any measure), have no presence in the film. Denial becomes an aberrative act of a bullying, pathological, morally corrupt antagonist, not the foundation of contemporary social and political life. In this way, the film does a tremendous disservice and actually reinforces the broader and more potent denial invisible in it: by pretending that the worst of denial is David Irving, like the fox who, with stick in mouth, backs into a pond to force its fleas off it onto the stick, the film allows us to conceptually push all of the denial that pervades our lives onto the Irving figure. I do not mean to suggest that typical people are anything like David Irving - taken discretely, Holocaust denial is incontrovertibly one of the worst forms of denial in moral terms-but by presenting him as emblem or epitome of denial and in essence the entirety of denial, the implication is that his defeat was a great defeat for denial, instead of an opportunity through which we might push the battle against denial, against the manipulation of the distance between rhetoric and reality. The film could have represented Irving as the tip of the denial iceberg, so to speak, alerting us to its pervasive presence and the danger it poses, before our ship goes down. Instead, the film retreats from this major political potential, into a nice Hollywood happy ending.

\section{Bibliography}

Anonymous (posted by WewelsburgSS). "David Irving: Talking Frankly." YouTube video, March 22, 2016. 2:18:06. Accessed June 25, 2017. https://www.youtube.com/watch?v=97L SJrPl6g. Ararat. Atom Egoyan, dir. 2002; Canada, et al.: Alliance Atlantis Communications et al. 115 min.

Baudrillard, Jean. Simulacra and Simulation. Translated by Sheila Faria Glaser. Ann Arbor: University of Michigan Press, 1994.

Berkeley, George. Three Dialogues between Hylas and Philonous. Indianapolis: Hackett, 1979.

Bradshaw, Peter. “Denial Review: Overwhelming Relevant Assertion of Truth." Guardian, January 27, 2017. Accessed November 1, 2017. https://www.theguardian.com/film/2017/jan/26/ denial-review-holocaust-rachel-weisz.

\footnotetext{
${ }^{22}$ Human Rights and Equal Opportunity Commission, Bringing Them Home: Report of the National Inquiry into the Separation of Aboriginal and Torres Strait Islander Children from their Families (Canberra: Human Rights and Equal Opportunity Commission, 1997).

${ }^{23}$ Anna Haebich, "Reflecting on the Bringing Them Home Report," Genocide Perspectives V: A Global Crime, Australian Voices, ed. Nikki Marczak and Kirril Shields (Sydney: UTS P/Sydney UP, 2017$), 31$.

${ }^{24}$ Bart Schultz, “Mill and Sidgwick, Imperialism and Racism," Utilitas 19, no. 1 (2007), 106.
} 
Brandt, George. "Brecht, Bertolt." In The Continuum Companion to Twentieth Century Theatre, edited by Colin Chambers. London: Continuum, 2010. Accessed June 17, 2017. http://www.oxfordreference.com.ezproxy.library.uq.edu.au/view/10.1093/ acref/9780199754724.001.0001/acref-9780199754724-e-362?rskey=uD4hD5\&result=1.

Carroll, Noël. The Philosophy of Motion Pictures. Malden: Blackwell Publishing, 2008.

Charny, Israel W. "A Contribution to the Psychology of Denial of Genocide." Genocide and Human Rights: Lessons from the Armenian Experience. Special issue, Journal of Armenian Studies 4, nos. 1-2 (1992), 289-306.

Descartes, René. Meditations on First Philosophy, 3rd ed. Translated by Donald A. Cress. Indianapolis: Hackett, 1993.

Denial. Mick Jackson, dir. 2016; UK/Poland, et al.: BBC/Krasnoff et al. 109 min.

Des Pres, Terrence. "On Governing Narratives: The Turkish-Armenian Case." Yale Review 75, no. 4 (1986), 517-531.

Hegel, Georg.W.F. The Phenomenology of Spirit. Translated by A.V. Miller. Oxford: Oxford University Press, 1977.

Foucault, Michel. "Right of Death and Power over Life." The History of Sexuality Vol. 1: An Introduction, reissue ed. London: Vintage, 1990.

Haebich, Anna. "Reflecting on the Bringing them Home Report." Genocide Perspectives V: A Global Crime, Australian Voices, edited by Nikki Marczak and Kirril Shields, 26-42. Sydney: UTS P/ Sydney UP, 2017.

Human Rights and Equal Opportunity Commission. Bringing Them Home: Report of the National Inquiry into the Separation of Aboriginal and Torres Strait Islander Children from their Families. Canberra: Human Rights and Equal Opportunity Commission, 1997.

Kershaw, Ian. The Nazi Dictatorship: Problems and Perspectives of Interpretation. London: Edward Arnold, 1985.

Leuchter, Fred A. The Leuchter Report: The End of a Myth. Newport Beach, CA: Samisdat Publishers, 1988.

Lipstadt, Deborah. History on Trial: My Day in Court with a Holocaust Denier. New York: Harper Perennial, 2005.

Mill, John Stuart. On Liberty. Indianapolis: Hackett, 1978.

Nietzsche, Friedrich. On the Genealogy of Morals. Translated by Walter Kaufmann and R.J. Hollingdale. On the Genealogy of Morals and Ecce Homo, 15-66. New York: Vintage Books, 1989.

Marx, Karl and Frederick Engels. The German Ideology. Marx Engels Archive. Accessed June 11, 2018. www.marxists.org/archive/marx/works/1845/german-ideology/.

Plato. The Republic. Translated by Benjamin Jowett. Internet Classics Archive. Accessed June 10, 2018. www.classics.mit.edu/Plato/republic.8.vii.html.

Rand, Ayn. The Fountainhead, 25th edition. New York: Signet, 1996.

Schultz, Bart. "Mill and Sidgwick, Imperialism and Racism." Utilitas 19, no. 1 (2007), 104-130. https://doi.org/10.1017/S095382080600238X

Smith, Murray. Engaging Characters: Fiction, Emotion, and the Cinema. Oxford: Clarendon Press, 1995. Snyder, Timothy. Bloodlands: Europe Between Hitler and Stalin. London: Vintage, 2010.

Weichselbaum, Simone. "Nearly One in Four Brooklyn Residents are Jews, New Study Finds." New York Daily News, June 26, 2012. Accessed May 24, 2017. http://www.nydailynews.com/newyork/brooklyn/brooklyn-residents-jews-new-study-finds-article-1.1100080.

Wiesel, Elie. Night. Translated by Marion Wiesel. New York: Hill and Wang, 2006. 